IZSÁKI ZOLTÁN:

\title{
A szarvasi mütrágyázási tartamkísérletek eredményei I. (1990-2010) Kukorica, cukorrépa, zab, olajlen és silócirok tápanyagellátása
}

(Agroinform Kiadó és Nyomda Kft. Budapest, 2016)

A hazai növénytermesztési és agrokémiai kutatások eredményeire épülő trágyázási ajánlások és szaktanácsadási rendszerek több mint száz éves múltra tekintenek vissza. Magukba foglalják mindazon tudományos és gyakorlati ismereteket, melyek korábban felhalmozódtak. A növénytáplálás komplex tudományos ismeretek szintézisére alapozódik. Elválaszthatatlan az agrokémiai, a növényélettani, a talajtani és a növénytermesztési tudomány fejlődésétőll, azok tudományos eredményeitől. Az agrárkutatás igényli a kitekintést, a távlatot mind térben, mind időben. Sikere a hosszú távú és előretekintő kísérletezésen múlik. A hazai mütrágyázási tartamkísérletek a trágyázási szaktanácsadás fejlesztésére alapvető tudományos hátteret biztosítanak. A tartamkísérletek továbbá nemzeti értéket képviselnek az agrár- és környezetgazdálkodás számára.

A Szarvasi Mütrágyázási Tartamkísérleteket 1989-ben állították be NPK 4-4 ellátottsági szinten, 64 trágyázási kezeléssel és évente négy növénnyel. A tartamkísérlet két évtizede alatt 10 szántóföldi kultúra szerepelt. A kutatási eredményeket és a tapasztalatokat összefoglaló könyv első kötete öt növény (kukorica, cukorrépa, zab, olajlen és silócirok) tápanyagellátásával foglalkozik. Az olvasó logikus felépítésü, gondosan összeállított, komplex szemléletü, élvezetes stílusú és szakmai igényességgel megírt könyvet vehet a kezébe. A klasszikus talajtermékenységi - agrokémiai - növénytáplálási kutatási eredmények tárházát találja ebben a munkában.

Az okszerü tápanyagellátás nem nélkülözheti az egzakt szántóföldi kísérletek alapján szerezhető ismereteket talajaink tápanyagszolgáltató-képességéröl. A könyv 20 kísérleti év részletes talaj- és tápelem-felvételi vizsgálatai és tápelem-forgalmi számításai alapján jellemzi a csernozjom réti talaj tápelem-szolgáltatását. Ismerteti a N-, P- és K-mütrágyázás hatását a talaj tápelem-tartalmának változására, a $\mathrm{NO}_{3}-\mathrm{N}$ felhalmozódására és kimosódására. Kimutatja, hogy a nagyobb termőképességü és kedvezőbb harvest indexű fajták termesztésbe vonásával változás mutatható ki egyes növényfajok fajlagos tápelem-felvételében. A tartamkísérlet részeként végzett tápelem-forgalmi vizsgálati adatok a kísérleti növények tápelem-felvételét és felvételi dinamikáját részletesen mutatják be. 
A trágyázási szaktanácsadás fejlesztésének ma is fontos eleme a szántóföldi termőhelyek tápelem-ellátottsági határértékeinek az egyes növénycsoportok, illetve növényfajok tápelem igényére vonatkozó pontosítása. Ilyen típusú vizsgálatokra azon kísérletek alkalmasak, amelyek kalibrációs jellegúek és képesek kimutatni a talaj tápanyag-ellátottsága és a terméshozam kapcsolatát. A szarvasi kísérletek metodikája ezt lehetővé teszi és választ ad arra, hogy milyen tápanyag-ellátottsági szintig számíthatunk terméshozam növekedésre, jobb termésminőségre és hol következhet be termésdepresszió és minőségromlás.

A korszerű növénytermesztés olyan trágyázási gyakorlatot kíván alkalmazni, mely környezetkárosítás nélkül biztosítja a növény tápanyagigényének kielégítését gazdaságos termésszint és jó termékminőség elérésével. A könyv egyes fejezetei ehhez hasznos támpontokat nyújtanak, ismertetve az egyes növények trágyázásterméshozam és termésminőség kapcsolatát.

A tudományos alapokon nyugvó trágyázási szaktanácsadási rendszernek szerves része a diagnosztikai célú növényanalízis, mely alkalmas a növény tápláltsági állapotának megállapítására, az abszolút vagy relatív tápelem hiány vagy túlsúly kimutatására, valamint a rejtett táplálkozási zavarok feltárására és a trágyázási gyakorlat ellenőrzésére. A tenyészidőszakban végzett növényanalízis e feladatnak csak akkor tesz eleget, ha a növény tápláltsági állapotát jellemző tápelem-ellátottsági határértékek megbízhatóan kalibráltak. A tartamkísérletben végzett növényelemzések adatbázisának értékelése alapján a szerző ismerteti a kísérleti növények kielégítő tápelem-ellátottságának határértékeit összevetve azokat a hazai és nemzetközi adatokkal.

A Szarvasi Mütrágyázási Tartamkísérleteket hazai és nemzetközi kutatási programok támogatták. A könyv igen komoly szakmai értéket képviselő hiánypótló munka, amely hazai és nemzetközi vonatkozásban is fontos tudományos és a gyakorlatban is jól hasznosítható eredményeket tesz közzé, kiegészítve azokat széleskörű irodalmi eredményekkel és ismeretekkel. A közölt kísérleti eredmények, adatok megállapítások nem avulnak el, értékük a jövőben is hasznosítható. Beépítésük a szaktanácsadási gyakorlatba megalapozott és racionális gazdálkodást eredményez. A kiadvány egyaránt ajánlható az oktatás, a kutatás, a szaktanácsadás és a termelés területén dolgozó növénytáplálás iránt érdeklődő szakemberek számára.

Érkezett: 2015. február 10.

KÁDÁR Imre

MTA Agrártudományi Kutatóközpont Talajtani és Agrokémiai Intézet, Budapest

Postai cím: KÁDÁR IMRE, MTA Agrártudományi Kutatóközpont Talajtani és Agrokémiai Intézet, 1022 Budapest, Herman Ottó út 15.E-mail: kadar@rissac.hu 